\title{
Prevalence of Virological Markers HIV, HBV and HCV in Homozygous Sickle Cell Patients at Brazzaville University Hospital
}

\author{
Laure Flora Josiane Kibangou1, Rachel Moyen ${ }^{2}$, Nanikaly Moyen ${ }^{3}$, Innocent Kocko4, \\ Lydie Ngolet ${ }^{4}$, Ettienne Nguimbi ${ }^{2}$, Alexis Elira Dokekias ${ }^{5}$ \\ ${ }^{1}$ National Blood Transfusion Center, Brazzaville, Congo \\ ${ }^{2}$ Laboratory of Cellular and Molecular Biology, Faculty of Science and Technology, Marien Ngouabi University, \\ Brazzaville, Congo \\ ${ }^{3}$ Laboratory of Virology and Hematology, Faculty of Health Sciences, Université Marien Ngouabi, Brazzaville, Congo \\ ${ }^{4}$ Clinical Hematology Department, University Hospital of Brazzaville, Brazzaville, Congo \\ ${ }^{5}$ National Reference Center for Sickle Cell Disease, Brazzaville, Congo \\ Email: kibangoulaure@gmail.com, ^rmoyen@yahoo.fr
}

How to cite this paper: Kibangou, L.F.J., Moyen, R., Moyen, N., Kocko, I., Ngolet, L., Nguimbi, E. and Dokekias, A.E. (2021) Prevalence of Virological Markers HIV, HBV and HCV in Homozygous Sickle Cell Patients at Brazzaville University Hospital. Open Journal of Blood Diseases, 11, 140-149. https://doi.org/10.4236/ojbd.2021.114014

Received: April 26, 2021

Accepted: December 14, 2021

Published: December 17, 2021

Copyright $\odot 2021$ by author(s) and Scientific Research Publishing Inc. This work is licensed under the Creative Commons Attribution International License (CC BY 4.0).

http://creativecommons.org/licenses/by/4.0/

\section{(c) (i) Open Access}

\begin{abstract}
In order to evaluate the seroprevalence of major viral markers, a descriptive study was carried out in homozygous sickle cell transfusion patients at the University Hospital of Brazzaville. The profiles were determined in 51 patients, 32 of whom were male and 19 female, with an age range of 17 to 51 years, admitted to the clinical hematology department of the University Hospital and to the National Reference Center for Sickle Cell Disease. The tests were performed on pre- and post-transfusion blood samples. The following reagents were used: GeenscreenTMultraHIVAg-Ab, MonolisaAg-HBs plus, MonolisaHCV Ag-Ab Ultrade Bio-Radot for the detection of HIV, HBV and HCV by fourth generation ELISA tests (serological tests). The results showed that the indications for blood transfusion were: acute crises of anemia due to malaria and in some cases of Vaso-Occlusive Crises (VOC) resistance to analgesic treatment. The prevalence rates of the markers before the new transfusion were respectively: HIV: $0 \%$, HBV: $1.96 \%$, HCV: $3.92 \%$. After transfusion, the final seroprevalence rates of the markers are: HIV: $0 \%$, HBV: $5.88 \%$, HCV: $3.92 \%$. The seroconversion rate for HBV was $3.92 \%$. One case of $\mathrm{HBV}+\mathrm{HCV}$ co-infection (1.96\%). Conclusion: Transfusion safety is achieved through good transfusion practices and the qualification of blood donations. Homozygous sickle cell disease, characterized by frequent anemia attacks, requires a guarantee of efficient transfusion practices in order to limit microbial risks.
\end{abstract}

\section{Keywords}

Safety, Poly Transfusion, Sickle Cell Disease, Poly Transfusion, Brazzaville 


\section{Introduction}

Blood transfusion is a potentially life-saving intervention that plays an essential role in the management of patients in health care systems [1]. However, it remains fraught with many risks. Residual transfusion risk remains for several infectious agents [2] [3] [4]. Transfusion safety is the basis of blood transfusion and comprises several links, including good collection practices, donor selection, biological qualification of blood donations and distribution of labile blood products (LBS) [5]. Screening for infectious agents is a very important step in the process of biological qualification of blood donations in virology. It contributes to the prevention of transmission of viral diseases following blood transfusion or its derivatives in the population [6]. Among the virological markers, the presence of the major viruses, in particular HIV, HBV and HCV, is noted. The techniques for detecting these markers are very often limited to serological analyses, sometimes using rapid tests [7] [8] [9]. In Black Africa, the infectious safety of labile blood products is a key concern for blood transfusion centers because of the high prevalence of viral markers in the population [10] [11] [12] [13] [14]. Globally, there are significant variations in the screening tests performed, the strategies adopted for screening, and the overall quality and efficiency of the blood screening process [2]. In many countries, therefore, recipients of blood and blood products remain at an unacceptable risk of acquiring life-threatening infections. However, the residual risk of transmission of infectious agents has been significantly reduced. The feared silent window in infections (HIV, HBV and HCV) has been significantly reduced by the introduction of many reagents on the market [15] [16] [17].

The aim of our work is to evaluate the seroprevalence of major viral markers that pose a threat to transfusion safety in patients with sickle cell disease in the homozygous form.

\section{Materials and Methods}

\subsection{Material}

It consisted of blood samples taken from transfused sickle cell patients, in consultation in health care centers.

\subsection{Method}

This was a descriptive study conducted at the clinical hematology department of the Brazzaville Hospital and University Center (CHUB) and at the National Reference Center for Sickle Cell Disease (CNRD) between May and December 2017.

The inclusion criteria were:

Patients with sickle cell disease in its homozygous form, a condition confirmed by a previous diagnosis (hemoglobin electrophoresis at alkaline $\mathrm{pH}$ ).

Patients with a history of transfusion.

Patients aged 17 years and older.

Patients who agreed in writing, after reading the consent form (parent consent 
for minor patients).

The criteria for non-inclusion were:

Patients with no established diagnosis of sickle cell disease.

Patients with no history of transfusion.

Patients under 17 years of age;

Patients (or parent of minor) not consenting to the study.

Study variables were: sex, age, education level, sexual activity, serological status before and after the new transfusion, and number of erythrocyte units received.

The sample

A total of 96 sickle cell patients consulted during the study period were transfused and only 51 patients met the inclusion criteria.

Sampling technique: two samples were taken with a gap of 2 months (to observe the serological window) before and after the new transfusion. The $5 \mathrm{ml}$ venous blood sample was collected at the elbow in a dry tube. The collected samples were sent to the CIDTS laboratory for centrifugation (with a TDL-80-2B centrifuge), 48 hours after collection, at $3000 \mathrm{rpm}$ for 5 minutes, and the serum obtained was placed in aliquots in $2 \mathrm{ml}$ cryotubes and stored at $-20^{\circ} \mathrm{C}$. Same procedure 02 months later at control sampling.

Serological analysis was performed at the National Blood Transfusion Center (CNTS) on the serum from the samples no later than 48 hours after collection.

The serological analysis technique: the search for viral markers was carried out by the 4th generation ELISA (Enzyme LinkedImmuno-sorbantAssay) test, which is a practical, sensitive method that visualizes enzymatic activity and detects both antibodies and antigens in the plasma. The reagents (from Bio-Rad) used were: for HIV: GenscreenTM ULTRA HIV Ag-Ab, for HBV: Monolisa HBsAg plus, for HCV: Monolisa HCV Ag-Ab ULTRA2 [2] [18] [19]. The procedure consisted of distribution of samples and control seras into the microplate wells and then distribution of the conjugate, incubation, washing (at BioRAD's $\mathrm{PW} \leq 0$ washing device) and then revelation of the solid phase bound enzyme activity by adding the substrate; stopping the revelation and then reading the optical densities (OD) on the hP brand reader at 450/620 nm and interpretation of results.

Statistical analysis: data entry and analysis were done on a microcomputer using Excel 2007 and SPSS software, the chi2 test was used for comparison of proportions.

\section{Results and Discussion}

Out of 96 patients who received a blood transfusion, 51 met the criteria, i.e. a frequency of $53.12 \%$.

\subsection{Distribution of Patients According to Age Range and Gender}

The distribution of the poly perfused patients according to sex gave 19 male pa- 
tients $(37.26 \%)$ and 32 positive female patients $(62.74 \%)$ with a sex ratio of 0.59 . The age of the patients ranged from 17 to 51 years with an average age of 24 years. According to the defined age ranges, 11 male (21.57\%) and 13 female (25.49) patients were between 17 and 25 years of age; 7 male (13.72\%) and 12 female (23.53\%) patients were between 25 and 35 years of age; 1 male (1.96\%) and 7 female $(13.72 \%)$ patients were between 35 and 51 years of age. The results of this distribution are shown in Figure 1.

\subsection{Distribution of Patients According to Education Level and Sexual Activity}

The results of these variables showed that 3 patients $(5.88 \%)$ had no education and all of them were sexually active; 7 patients (13.72\%) had a primary level of education, of which 5 were sexually active (9.80\%); 32 patients of which 27 were sexually active had a secondary level of education and 9 patients of which 8 were sexually active had a higher level of education. These data showed that $52.94 \%$ of the patients with sexual activity corresponded to those with a secondary level of study. The results are shown in Figure 2.

\subsection{Distribution of Patients According to Erythrocyte Unit Transfused}

Out of 51 patients tested, 42 received two red blood cell units or concentrates corresponding to two blood bags, i.e. $82.35 \%$ of patients, and 9 patients received a single blood bag (17.65\%).

\subsection{Evolution of the Number of Transfusions Per Patient}

Out of 51 patients, $20(39.22 \%)$ were transfused 6 times or more. The other

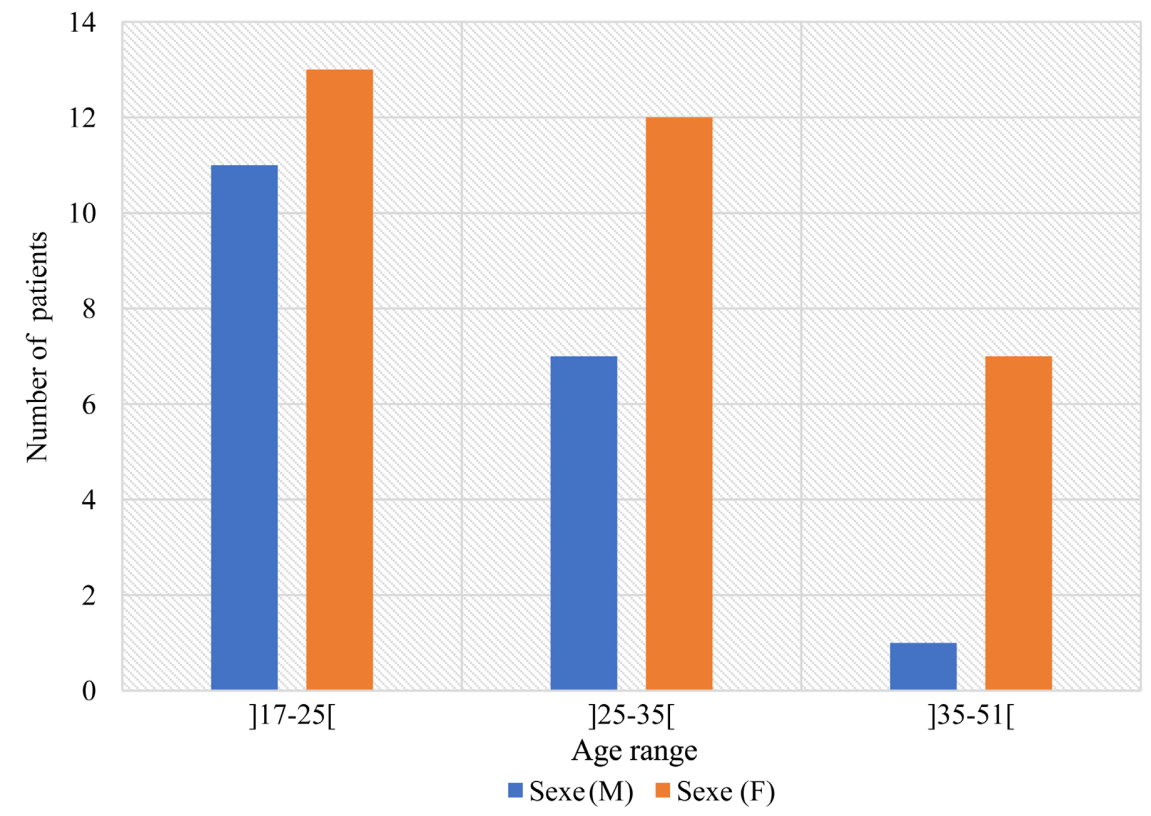

Figure 1. Distribution of patients according to age and sex. 


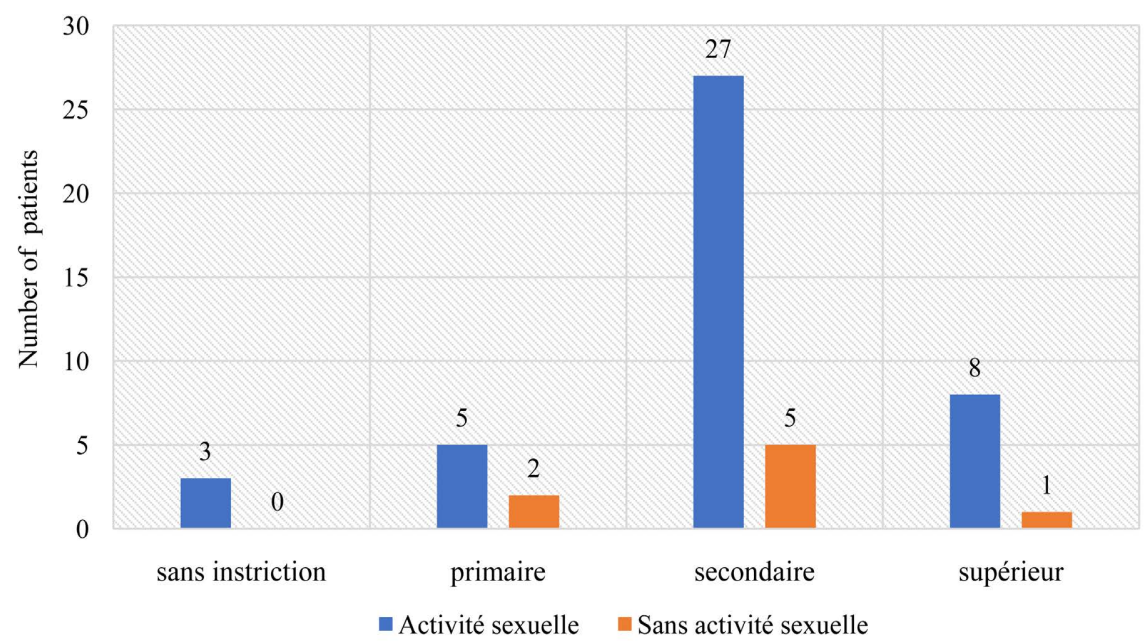

Figure 2. Distribution of patients according to education level and sexual activity.

patients received the number of infusions varying from 2 to 5 as shown in Figure 3.

\subsection{Virological Profile of HIV, HBV, HCV Markers before and after the New Transfusion}

The results obtained show that, in the case of the HIV (human immunodeficiency virus) marker, no test was positive before and after the new transfusion in all patients.

However, some patients tested positive for hepatitis B (HBV) and hepatitis C (HCV) markers, including one hepatitis B positive patient aged between 17 and 25 years. The results are shown in Figure 4 and Figure 5, respectively.

Before the new transfusion, 50 patients were negative for hepatitis B virus (HBV 98.04\%) and 1 female patient aged 21 years was positive (1.96\%).

After the new transfusion, the HBV marker assay yielded two new positive patients, one male aged 22 years and the other female aged 45 years. These results show a predominance of HBV markers in female patients and established seroconversion in two patients.

In the case of hepatitis $\mathrm{C}$, two patients were positive before and after the new transfusion. The two HCV-positive patients were female, one 26 years old and the other 45 years old.

A total of $5 \mathrm{HBV}$ and HCV marker positive patients were observed.

A post-transfusion $\mathrm{HBV}+\mathrm{HCV}$ co-infection was observed in one patient aged 45 years, with a representativeness of $20 \%$. The results are shown in Figure 6.

\section{Discussion}

In our study the mean age was 24 years with extremes of 17 and 51 years. Polytransfused patients living with sickle cell disease in the homozygous form were 


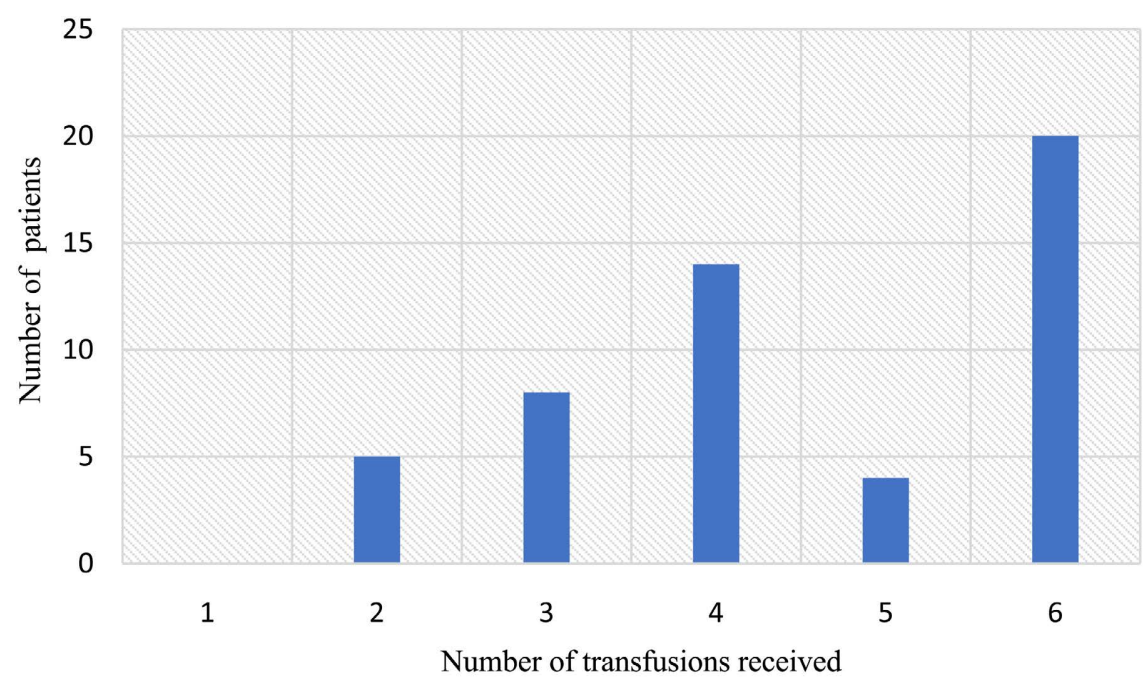

Figure 3. Number of transfusions received by patients

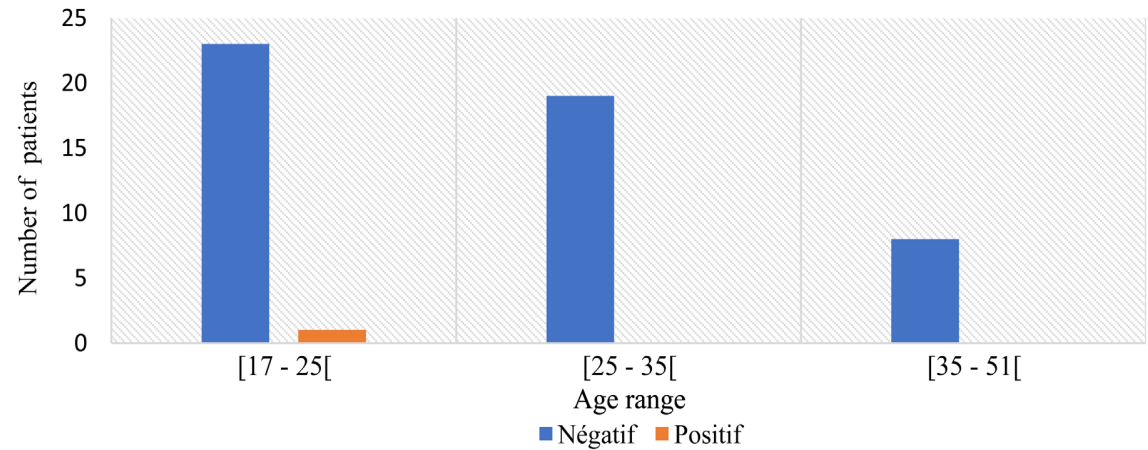

Figure 4. Distribution of patients with respect to pre-transfusion HBV marker by age range.

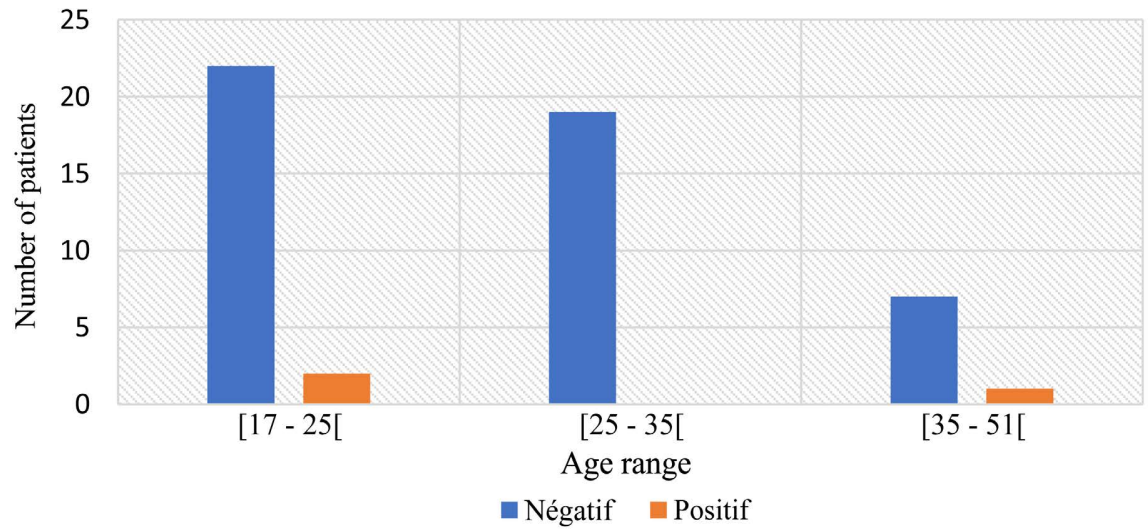

Figure 5. Post-transfusion seroconversion of patients to HBV marker.

more numerous in the age group of 17 to 25 years, i.e. $47.06 \%$. The female sex was the most representative: $62.75 \%$ against $37.26 \%$ for the male sex, i.e. a sex ratio of 5.9.

DIARRA.A.B. et al. [8] also found a higher number of women than men. 


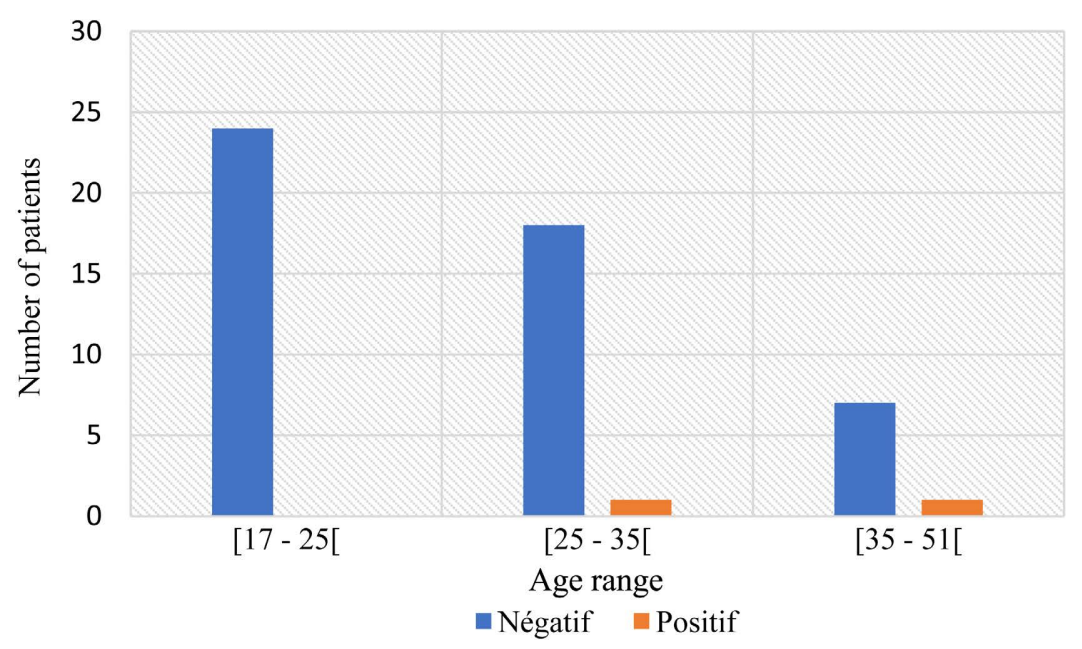

Figure 6. Pre- and post-transfusion HCV marker by age range.

Concerning the level of education, 5.88\% of patients did not attend school, $52.94 \%$ had secondary education, only $15.69 \%$ of patients had reached higher education. NZINGOULA.S. [15] found that $40.25 \%$ of boys and $46.7 \%$ of girls were behind in school and $13 \%$ of children were not in school in a study on sickle cell disease [20] [21] [22].

Serological monitoring of markers showed that in the case of HIV, no patient carried the HIV marker before and after transfusion, i.e. 100\% seronegative patients. These results are similar to those obtained in Marseille by BLOUIN et al. [23] who showed that there were no post-transfusion incidents related to HIV. These results can be explained by the reinforcement of transfusion safety measures. However, the work carried out by LAPERCHE [24] in France observed two (2) cases of HIV-related contamination. These differences may be due to the methodology adopted and the duration of the study.

In the case of HBV:

The pre-transfusion results show that, out of a total of 51 patients, 50 patients (98.04\%) were HBV negative and 1 patient was HBV positive (1.96\%).

The post-transfusion results show 48 patients $(94.12 \%)$ seronegative and 3 patients (5.88\%) seropositive to HBV, which shows a seroconversion rate of $3.92 \%$.

These HBV positive patients are found in the age range of $22-45$ years with declared sexual activity. In our study, several patients admitted to having unprotected sex. The hepatitis B marker values obtained are similar to those of NGOSACK et al. [25] in Cameroon, who worked on 108 polytransfused patients of whom 7 were $\mathrm{HBV}$ positive (6.48\%). Their results also showed that the positive patients were between 21 and 30 years of age and that contamination was largely through sexual contact.

Concerning the Hepatitis $\mathrm{C}$ virus, the results of the 1st and 2nd tests were the same: 49 seronegative patients $(96.08 \%)$ and 2 seropositive patients (3.92\%). NGOSACK et al. [25] showed that the prevalence of. HCV antibody in polytransfused patients increased with the number of transfusions received and with 
the age of the patients. The work of ATIPO IBARA et al. [26] carried out on 74 HCV seropositive patients showed that 59 of them were female (20\%) with an average age of $31 \pm 7.6$ years with extremes ranging from 18 to 52 years. They showed that the most common risk factor for HCV contamination was tattooing or scarification (44.6\%) followed by blood transfusion (36.6\%).

The results of our study showed only one case of HBV + HCV co-infection. This was a 45 year old patient, seropositive to both HBV and HCV, and therefore a HBV + HCV case with a prevalence of $1.96 \%$. This result is higher than that obtained by ELIRA et al. and Attia et al. [13] [27], who found HBs + HCV co-infections of $0.14 \%$.

\section{Conclusions}

The virological profile of polytransfused patients living with sickle cell disease in the homozygous form at the University Hospital of Brazzaville can be considered satisfactory for HIV with no positive cases, but unsatisfactory for HCV with 2 positive cases and HBV with 3 positive cases for the population of the present study. The observed seroconversion reminds us that blood transfusion is not always risk-free. Thus, for maximum transfusion safety, a rigorous selection of blood donors and a biological qualification of blood products are necessary. To stop the rapid spread of these infections, more precise screening must be carried out using molecular biology tests.

Access to care and non-compliance with preventive methods are challenging to be met. Thus, transfusion safety is achieved through good transfusion practices and the qualification of blood donations.

\section{Proposed Algorithms}

In view of the seriousness of infections due to major viruses and the existence of co-infections between these viruses, we encourage the health authorities to apply effective means of prevention such as rigorous selection of blood donors.

The suggestion to the public authorities is to systematize the vaccination against hepatitis B and the systematic screening by efficient tests of hepatitis C.

\section{Conflicts of Interest}

The authors declare no conflicts of interest.

\section{References}

[1] Organisation mondiale de la Santé (2010) Dépistage des infections transmissibles par transfusion dans les dons de sang: Recommandations. 81.

[2] Kashosi, T.M., et al. (2018) Field Accuracy of HIV Rapid Diagnostic Tests for Blood Donors Screening, Bukavu, Eastern Democratic Republic of the Congo. The Journal of Infection in Developing Countries, 12, 471-476. https://doi.org/10.3855/jidc.9774

[3] Hannachi, N., Boughammoura, L., Marzouk, M., Tfifha, M., Khlif, A., et al. (2011) Le risque infectieux viral chez le polytransfusé: Séroprévalence de sept agents viraux dans le centre tunisien. Bulletin de la Société de Pathologie Exotique, 104, 220-225. 
https://doi.org/10.1007/s13149-010-0103-7

[4] Kabinda, J.M., Bulabula, A.N., Donnen, P., Fiasse, R., Van den Ende, J., et al. (2014) Residual Risk of Transmission of HIV and Hepatitis B and C by Blood Transfusion in Bukavu in the Democratic Republic of Congo. Open Journal of Epidemiology, 4, 157-163. https://doi.org/10.4236/ojepi.2014.43021

[5] Organisation Mondiale de la Santé (2002) Sécurité du Sang: Stratégie de la Région Africaine (AFR/RC 51/9 Rév.1). 3-4.

[6] Laouina, A., Adouani, B., Alami, R., Abouyoub, A., Hajjout, K. and Benajiba, M. (2016) Prévalence des marqueurs infectieux transmissibles par transfusion chez les donneurs de sang au CRTS de-Rabat (Maroc). Transfusion Clinique et Biologique, 23, 309-310. https://doi.org/10.1016/j.tracli.2016.08.118

[7] Cazenave, J.P. (2011) Inaction photochimique des pathogènes des plaquettes et du plasma: Cinq ans d'utilisation clinique de routine et d'hémovigilance. Vers un changement de paradigme de la sécurité en transfusion. Transfusion Clinique et Biologique, 18, 51-61. https://doi.org/10.1016/j.tracli.2011.02.023

[8] Diarra, A.B., et al. (2013) Sécurité transfusionnelle et drépanocytose à Bamako, Mali séroprévalence des infections à VIH, VHB, VHC (allo-immunisation anti-Rh et Kell chez les drépanocytaires). Transfusion Clinique et Biologique, 20, 476-481.

https://doi.org/10.1016/j.tracli.2013.04.111

[9] Fieury, H.A.J.A. (2002) Virologie humaine. Masson, Paris, 245, 43167.

[10] Programme commun des Nations Unies sur le VIH/Sida, journée mondiale sida 2001. Rapport ONUSIDA, 10-11.

[11] Elira, D.A., Okandze Elenga, J.P., Dzia, L.A. and Garcia, S. (2002) Séroprévalence des marqueurs viraux chez les donneurs de sang à Brazzaville. Transfusion Clinique et Biologique, 8, 84-89.

[12] Candotti, D., Sarkodie, F. and Allain, T.P. (2001) Residual Risk of Transfusion in Ghana. British Journal of Haematology, 113, 37-96. https://doi.org/10.1046/j.1365-2141.2001.02679.x

[13] Elira, A., Okandze Elenga, J.P., Gouary, A.S., et al. (2003) Séroprévalence de l'hépatite virale chez les malades polytransfusés au CHUB. Bulletin de la Société de Pathologie Exotique, 96, 279-282.

[14] Elira, D.A., Ngolet, O.L., Atipo, T.F.O., Malanda, F., Koko, I. and De Montalembert, M. (2009) Evaluation de la transfusion sanguine chez 112 patients drépanocytaires homozygotes au CHU de Brazzaville. Transfusion Clinique et Biologique, 16, 464-470. https://doi.org/10.1016/j.tracli.2009.01.003

[15] Nzingoula, S. (1991) Hôpital et drépanocytose, service de pédiatrie CHU de Brazzaville in Drépanocytose et santé publique. Ed CIE/INSERM, 61-64.

[16] Centre National de la Statistique et des études Economiques (2009) Enquête de séroprévalence et sur les indicateurs du sida au Congo (ESI SC-1). Rapport de synthèse Brazzaville, 1-11.

[17] Mbendi, C., Lombi, N., Longo-Mbenza, B., Ndendisukini, S., et al. (2001) Prévalence du VIH et de de l'antigène HBs chez les donneurs du sang. Risque résiduel de contamination chez les receveurs de sang à Kinshasa-Est, République Démocratique du Congo. Medecine Tropicale, 61, 139-142.

[18] Keen, P., Conway, D.P., Cunningham, P., McNulty, A., Couldwell, D.L., Davies, S.C., Smith, D.E., et al. (2017) Multi-Centre Field Evaluation of the Performance of the Trinity Biotech Uni-Gold HIV 1/2 Rapid Test as a First-Line Screening Assay for Gay and Bisexual Men Compared with 4th Generation Laboratory Immunoassays. Journal of Clinical Virology, 86, 46-51. 
https://doi.org/10.1016/j.jcv.2016.11.006

[19] Amini, A., Varsaneux, O., Kelly, H., Tang, W., Chen, W., Boeras, D.I., Falconer, J., Tucker, J.D., Chou, R., Ishizaki, et al. (2017) Diagnostic Accuracy of Tests to Detect Hepatitis B Surface Antigen: A Systematic Review of the Literature and Meta-Analysis. BMC Infectious Diseases, 17, 698. https://doi.org/10.1186/s12879-017-2772-3

[20] Empa, L. (1987) La drépanocytose au Congo: Fréquence observée sur une population de 887 nourrissons et enfants. Medecine d Afrique Noire, 28, 249-251.

[21] Labie, D. and Elion, J. (2010) La drépanocytose: Problème de l'Afrique. Medecine Tropicale, 70, 449-453.

[22] Ramakrishnan, M., Moisi, J.C., et al. (2010) Increased Risk of Invasive Bacterial Infections in African People with Sickele-Cell Disease: A Systematic Review and Meta-Analysis. The Lancet Infectious Diseases, 10, 329. https://doi.org/10.1016/S1473-3099(10)70055-4

[23] Blouin, P., Henquell, C., Odent, H. and Malaure, L. (2004) Bilan post-transfusionnel systématique géré par l'hémovigilance: 6 mois de fonctionnement. Société Française de vigilance et de thérapeutique transfusionnelle.

[24] La Perche, S. (1998) Les retombées pratiques des 3ans d'expériences de l'hémovigilance nationale en matière de complications virales. Transfusion Clinique et Biologique, 5, 211-218. https://doi.org/10.1016/S1246-7820(98)80413-8

[25] Françoise, N., et al. (2013) Portage de l'antigène HBs et des anticorps anti-VHC chez le drépanocytaire homozygote à l'hôpital central de Yaoundé. The Pan African Journal, 14, 1-6. https://doi.org/10.11604/pamj.2013.14.40.2069

[26] Atipo-Ibara, B.I., Mimesse, J., Bokilo-Dzia, A., Deby-Gassaye, Ahoui-Apendi, C., Bossali, F., Ngami, R.S. and Ibara, J.R. (2014) Virus de l'hépatite C: Etudes des génotypes au Congo (Brazzaville). Journal Africain d Hépato-Gastroentérologie, 8, 16-19. https://doi.org/10.1007/s12157-014-0506-3

[27] Attia, K.A. (2007) Coïnfection VIH-VHB au sud du Sahara: Données épidémiologiques, cliniques et thérapeutiques. Journal Africain d Hépato-Gastroentérologie, 1 , 51-53. https://doi.org/10.1007/s12157-007-0011-z 